\title{
THE DETERMINANTS OF POSITIVE CREATIVE ADAPTATION OF YOUTH IN THE POLISH-CZECH BORDERLAND
}

\author{
Alina SZCZUREK-BORUTA (D) * \\ Institute of Pedagogy, Faculty of Social Sciences, University of Silesia in Katowice, \\ Bankowa 12, 40-007 Katowice, Poland
}

Received 22 December 2020; accepted 27 May 2021

\begin{abstract}
The article is aimed at diagnosing the determinants of youth's positive adaptation to changing demands of life. It is focused on the relationships between creativity and resilience. The analysis comprised youth's adaptive competences and the resources and risks of social environment. In two measurement periods, quantitative-qualitative studies were conducted among youth in the Polish-Czech borderland. The research design enabled complex diagonal and longitudinal comparisons, which addressed: the identification and analysis of change trends, recognition of their lack, likelihood assessment of these trends in both compared cohorts.

The concept of resilience was used to analyse and interpret research results. The identification was conducted of (outer and inner) risk and protective factors determining positive adaptation in the Polish-Czech borderland. The borderland effect was indicated - the impact of borderland on its inhabitants' socialization, conditioned by spatial-social-cultural-economic properties. Attention was drawn to the forming of youth's flexibility, ability to handle everyday situations and their resistful behaviour patterns. Borderland is a source and stimulant for acquiring the disposition of resilience. The presented analyses show tendencies and universal mechanisms of human behaviour, not only in borderlands.

The article indicates the need for educational activities developing and forming resilience, for elaborating intervention programmes based on better use (in adaptation) of resources and protective factors in the environment.
\end{abstract}

Keywords: adaptation, borderland effect, creativity, educational intervention, resilience, youth.

\section{Introduction}

Modern times require a dynamic and flexible adaptation to the constantly changing demands of life. Such a situation results in an increasing interest in the conditions of positive adaptation.

The whole process of adaptation is culturally determined by the mechanism of social influence, which takes place through socialization, education, and enculturation. This mechanism decides which environmental factors (culture), in which social situations (social

${ }^{\star}$ Corresponding author. E-mail: alina.szczurek-boruta@us.edu.pl

Copyright (c) 2021 The Author(s). Published by Vilnius Gediminas Technical University

This is an Open Access article distributed under the terms of the Creative Commons Attribution License (http://creativecommons. $\mathrm{org} / \mathrm{licenses} / \mathrm{by} / 4.0 /$ ), which permits unrestricted use, distribution, and reproduction in any medium, provided the original author and source are credited. 
structure) and in which developmental categories (the individual's level of development) will shape some particular adaptive competences expected in a particular system of identification.

The discussion undertaken here is aimed at a diagnosis of the factors influencing positive adaptation of youth. My focus is on the borderland effect, understood as conditioning through the spatial and sociocultural properties of the course in which the socialization of borderland residents takes place or of the course of other social processes and phenomena observed there (the qualities of borderland are applied as explanatory ones). For the analysis and interpretation of research results concerning adaptation and its determinants, the concept of resilience is used.

Taking into consideration the scientific output of historians, ethnologists, sociologists, experts in political and cultural studies, borderland research has a long, over a hundred-yearsold history. There are two ways in which borderland is understood: as a specific territory or as a process of permeating social and cultural influences, not associated with a particular area. The borderland becomes rather a cultural, more symbolic than physical, space - therefore, it may be everywhere and everything may become a borderland. A lot of research possibilities come with Sadowski's concept of borderland. Apart from the spatial and sociocultural aspect, he indicates the personality-cultural aspect - a place in which a new human and their culture is shaped (Sadowski, 1992, 2008).

What becomes the foundation of borderland is the specificity of place and people, which results from the constant permeating of cultures in a particular social space (Sadowski, 1992; Gołdyka, 2016, p. 15). Within the Polish psychology of sociocultural borderland (Miluska, 2016) and pedagogy (Lewowicki, 1995a; Nikitorowicz, 1995), the category of borderland is used for presenting and explaining the sociocultural context of the individual's condition, the forming of competence, the construction of an identity, and the activities pertaining to intercultural education.

As regards history, the concept of resilience came into being as a result of the observation of children and youth growing up in unfavourable living conditions (Werner, 1994, 2000). Currently, resilience is a construct/term which is examined within positive psychology, sociology, and education. It gains particular significance in reference to personality, creativity, stress, health, and positive adaptation to the social environment.

According to Luthar et al., "resilience refers to a dynamic process encompassing positive adaptation within the context of significant adversity" (2000, p. 543). These authors made a critical assessment of the literature on resilience, jointly emphasizing the value of further studies on this complex construct.

In social sciences, the term resilience is a specific metaphor of many processes which constitute the phenomenon of proper functioning of an individual despite objectively unfavourable conditions of their individual development and life. Thus, resilience is a metaphor of the changing, time-dependent processes of balancing or neutralizing unfavourable conditions of life through inner and outer resources available to a person.

Resilience is often understood as a developmental process owing to which children acquire the skills of using the inner and outer sources to achieve a good adjustment (positive adaptation in spite of the past and current adversities) (Yates et al., 2003). It is a multidimensional construct, which comprises some important factors related to effective adaptation. 
From the standpoint of pedagogy and an educationalist, it should be stated that the ideal conditions for the development of children and youth can be ensured by shaping their resistance and creativity. The latter has been always recognized as one of the most important human qualities (creation in the sense of a personal quality is called creativity - cf. Nęcka, 2001, p. 19), a trait related to problem solving skills (Barron, 1969) and resilience (Csikszentmihalyi, 1996). Csikszentmihalyi defined creativity as "a process by which a symbolic domain in the culture is changed" (1996, p. 8) or, differently phrased, "creativity is any act, idea or product that changes an existing domain, or that transforms an existing domain into a new one" (1996, p. 8).

The concept of resilience - as I think - complies well with an interactive scheme of risk, deficits and reinforcements, care, support, resources of positive (creative) adaptation which takes place in the borderland.

What seems to be an interesting research field, a laboratory which allows one to verify concepts and theories, is the Polish-Czech borderland. It is the borderland territory between two countries, a place where the phenomena and processes which come from various spheres of social, cultural, political and economic life take place (Śliż \& Szczepański, 2016). This borderland is an area in which state and national interests clash and cultures and ideologies permeate. Although in the past, some tensions and conflicts, also armed ones (PolishCzechoslovak War in 1919), took place here, the borderland enhances mutual familiarization and the collaboration of people and their cultures (the phenomena particularly visible after 2004 - the Polish and Czech accession to the European Union (EU)).

It is assumed here that positive adaptation of youth is strengthened by some personal traits and social determinants of education, i.e. the risk and protective factors in the environment of life, socialization, and education. My thesis is that, in the borderland environment, there are both risk factors and resources for successful adaptation of children and youth. The process of interaction between risk and protective factors takes place there. Borderland is a source and stimulant for the development of resilience (effective adaptation) and resiliency (a particular personality trait) ${ }^{1}$. In the borderland, a moderate but constant risk level leads to the acquisition of resistful behaviour patterns, to the development of the ability to handle successfully and adequately everyday tasks in changing and often stressful situations. This increases the likelihood of life success and activates the positive mechanism of adaptation.

The discussion undertaken in the context of the borderland effect and resilience, as well as the conducted analyses, have due significance for education - they constitute the foundation for developing educational intervention, for designing programmes of educational activity that are based on both a better use of environmental resources - protective factors, and the influence of the existing threats - risks. The discussed issues are of importance for social and educational policies aimed at levelling the educational differences of people at various developmental stages, with special regard to people and environments affected by any type of marginalization.

\footnotetext{
${ }^{1}$ The term resilience is used here in reference to the process or phenomenon of competence, whereas the term resiliency is used only in regard to a particular personality trait (quoted in Luthar et al., 2000).
} 


\section{Methods}

Positive adaptation (quoted in Luthar \& Bidwell Zelazo, 2003; Masten \& Powell, 2003; Luthar, 2006) is a good adjustment to the environment despite the existing threats. The measure of positive adaptation is possessing the competences which are defined in terms of the effective fulfilment of developmental tasks, adequate to the age, culture, society, and historical period (Masten \& Obradović, 2006). Apart from personality traits, the process of adaptation is determined by social conditions of education (Szczurek-Boruta, 2007), i.e. the resources, protective factors, risks and threats related to the conditions and place of life, socialization, and education.

My studies on developmental tasks and social determinants of education have been conducted since 2003. Their results are presented in two authored monographs (SzczurekBoruta, 2007, 2019b). So far, I have also implemented two research projects pertaining to the diagnosis of the developmental tasks and social conditions of education in socially, culturally and economically diversified environments in three borderlands and three central parts of Poland. Another criterion of selecting the area was the gross domestic product per capita. The research comprised nearly 1500 people. All the studies so far have been carried out with the same tool - the authorial survey of developmental tasks and social conditions of education, the validity of which was confirmed in statistical analyses (Cronbach's alpha: 0.730$)^{2}$. The questionnaire is based on Erikson's (1994) theory of psychosocial development, Havighurst's (1981) concept of developmental tasks, Lewowicki's $(1994,1995 a)$ theory of identity behaviours, and sociological theories of conflict. A detailed description of the questionnaire can be found in the aforementioned publications as its characterization goes beyond the scope of this article ${ }^{3}$.

What has also been used in the studies is the narrative interview, partially directed and focused on a problem (Rubacha, 2008, pp. 136-140). The conducted interviews provide information about some personal, hidden, subjective theories which the young have and which pertain to different phenomena taking plane in their school space and environment of life.

The research of which results are addressed here are comprised in a comparative scheme (Frankfort-Nachmias \& Nachmias, 1996, pp. 153-154). The applied research design was complex and it enabled several types of elaborate diagonal and longitudinal comparisons (Schaie \& Strother, 1968). The simple time-lag analyses provide answers to the question: (How) do learners at the same age and from different demographic cohorts differ when examined in two different moments of time (in 2003/2004 and 2016/2017 school years)?; the complex diagonal-longitudinal (cohort-sequential) analyses provide answers to questions about a model of changes. The longitudinal comparisons and the cohort-sequential comparisons based on them help to identify and analyse the (progressive and regressive) trends in developmental changes, as well as to recognize the lack of changes (stagnation) and to evaluate the likelihood of these trends among the compared cohorts. The research group was selected with the use

\footnotetext{
2 Cronbach's alpha $(\alpha) 0.730$ (in the $0-1$ interval) confirms an appropriate construction of the questionnaire (Szczurek-Boruta, 2007, pp. 178-183).

3 The questionnaire comprises 48 questions in Part A (developmental tasks) and 41 questions in Part B (social conditions of education). There are 8 demographic questions (the questionnaire in Szczurek-Boruta, 2007, pp. 381-384).
} 
of purposeful-random sampling. The purposeful elements are: respondents' age - 18 years; type of school - secondary; residence place - the Polish-Czech borderland (the territory in the south of the Silesian Voivodeship (SV), Poland at the border with the Czech Republic and Slovakia). The area of the borderland Cieszyn County, Poland is $730.29 \mathrm{~km}^{2}$ and it is inhabited by 177124 residents. The population density is 243 inhabitants per $1 \mathrm{~km}^{2}$. All the administrative communes of the county belong to the Euroregion Cieszyn Silesia and they constitute the core of this Euroregion on the Polish side.

The research sample in both measurement periods $\left(2003 / 2004^{4}\right.$ and 2016/20175) fulfilled the criteria of representativeness ${ }^{6}$. Developmental tasks and social conditions of education were subjected to exploratory and comparative analyses. The analyses were based mostly on the respondents' opinions expressed in the questionnaire.

The collected research material was verified with the use of quantitative methods (statistical methods: testing the statistical significance of differences between the variables with chisquared test $(\chi 2)$, canonical analysis, factor analysis and descriptive statistics) and a qualitative description of the studies (Ferguson, 1989).

Taking the results of the conducted research ${ }^{7}$ into consideration, the answers to the following questions are sought in this study: What are the determinants of positive (creative) adaptation of youth living/functioning in the Polish-Czech borderland?

The analysis and interpretation of research results concerning adaptation and its determinants is conducted here with the use of the concept of resilience. I apply a broader sense of resilience, defined as a dynamic process reflecting a relatively good adjustment of the individual despite the experienced threats or traumatic experiences (Luthar, 2006; Luthar \& Bidwell Zelazo, 2003). This process comprises mutual impact of the whole spectrum of risk and protective factors (Olsson et al., 2003).

I recognize the interrelations between creativity and resilience, which are indicated, among other studies, in the research by Meneely and Portillo (2005). The concept of creative adaptation theoretically seems to be close to the concept of resilience. This is such a type of adaptation that inspires one's functioning in an exceptionally positive way, with simultaneous taking into account the environment and a specific context. Creative adaptation might be associated with Luthar's original definition of resilience $(2003,2006)$.

Due to the interactive character of resilience (indicated by Luthar \& Bidwell Zelazo, 2003; Luthar et al., 2006 and in a later work by Rutter, 2006), I did not measure resilience in a direct

\footnotetext{
4 The description of the examined group (195 learners) in the school year 2003/2004 and the research methodology in literature source by Szczurek-Boruta (2007).

${ }^{5}$ In the school year 2016/2017, the studies comprised 248 learners: 112 women and 136 men, 185 technical school learners and 63 learners from general education schools.

6 "As random sampling among all secondary school learners in the examined territory was organizationally very difficult, the decision was taken to carry out multistage sampling: random sampling of school and - within schools of class groups (Łobocki, 1999, pp. 167-168). The random number generator of Statistica 5.1 software was used. Taking into account that in social studies, a representative sample consists of 5, 10, 15 class groups $\mathrm{p}<0.05$ (Frankfort-Nachmias \& Nachmias, 1996; Ferguson, 1989), 8 class groups were subjected to the research (SzczurekBoruta, 2007, p. 172). The cohorts are not equal as the numbers of learners in the examined classes in 2003/2004 and in 2016/2017 were different.

${ }^{7}$ In this article, the results of my studies are placed in a different theoretical context and are presented in a different arrangement of problems than in the book by Szczurek-Boruta (2019b).
} 
way. I draw conclusions concerning resilience on the basis of measuring two separate dimensions: risk and protective resources (social conditions of education) and positive adaptation (an indicator of which is the fulfilment of developmental tasks).

In the conducted studies among youth, social conditions of education are the indexes of risk and protective factors - the resources determining the development and positive adaptation of youth. These are the developmental situations which provide a variety of experiences and reinforcements, as well as events, facts, and a set of people that influence the fulfilment of developmental tasks by the young. The following are treated by me as social conditions of education: "providing an identification offer", "prolonging the developmental moratorium", "broadening the interaction radius", "ethos", "ambivalence", "revitalization" (Szczurek-Boruta, 2007, pp. 132-147).

Risk in the context of resilience and borderland is approached here in the categories of the influence of certain factors on the individual's life. Among other things, the following are treated as risk factors: family conflicts; peer conflicts; conflicts with teachers; conflicts in the social environment of the ethnic, national, cultural or religious nature; rejection by peers; any discrimination; school failure. The occurrence of these specific factors may result in some particular types of problems or disorders. The co-occurrence or accumulation of the impact of many risk factors can be treated as an indicator of increased risk.

Competences are related to the individual's adaptive abilities, which consist in the use of inner and outer resources in order to pass through the consecutive developmental stages (Yates et al., 2003). As earlier mentioned, competences are defined in terms of effective fulfilment of developmental tasks (quoted in Masten \& Obradović, 2006).

A developmental task is a cognitive category explored in psychological studies mostly in the context of problems which a developing person has to solve (Thomas, 1990, pp. 118-120), vital, existential tasks (Erikson, 1994), and Havighurst's (1981) developmental tasks. In the sociological approach, fulfilling developmental tasks ensures both continuity and social changes. In the pedagogical perspective, the category of developmental tasks has been viewed by me as: a specific model of behaviour requirements typical of particular life phases; a constructive factor which specifies the structure of the educational reality and evaluates the described educational phenomena; a specific cultural code (Szczurek-Boruta, 2007, 2019b). In this study, the effective fulfilment of developmental tasks, such as: "achieving more mature relations with the peer group"; "managing the social role appropriate for one's gender"; "searching for a life partner - love"; "achieving emotional and economic independence from "others"; "acquiring a knowledge of oneself"; "acquiring competence in fulfilling school tasks"; "the choice and preparation for professional career"; "the understanding of the phenomena concerning social life (unemployment, politics, economy) as preparation for civil roles"; "changing and forming the surrounding reality"; "establishing a system of values", is treated here as a dimension of resilience, an indicator of positive adaptation. The familiarization with and understanding of developmental tasks is recognized by me as indispensable for successful acting for the development of children and youth, for wise regulation of the functioning of educational institutions and for teachers' better understanding of their practical workshop and measures. 


\section{Results}

Referring to Trudel et al. (2001), quoted in Simonet and Duchemin (2010), due attention is drawn in this study to the social and personal dimension of adaptation. Social adaptation is associated with the individual's participation in community or group life through fulfilling particular tasks and social roles in these groups. Yet, individual adaptation has a personal, subjective dimension and is associated with the individual's aiming at inner harmony, mental balance, well-being and satisfaction.

Some selected generalized results of the conducted generational studies of youth will be addressed here. In the further part of the article, they will become a reference point for indepth reflection upon positive adaptation of youth in the social and individual dimension and the determinants of this adaptation.

The research into the subject indicates that: the respondents' belonging to two different generations $\mathrm{Y}$ and $\mathrm{Z}$ (WJSchroer, 2020) ${ }^{8}$ did not turn out to be a differentiation factor in the case of the effectiveness in achieving competence and fulfilling developmental tasks - as a consequence, in positive adaptation. In the system of developmental tasks of both examined groups, there are no distinct dominants and the hierarchy is of a flattened character. Generally, two tasks: "the understanding of the phenomena concerning social life (unemployment, politics, economy) as preparation for civil roles" and "changing and forming the surrounding reality" in both demographic cohorts have not been sufficiently fulfilled by the young. The feeling of fulfilling all the developmental tasks by young people in both measurement periods is similar $(\bar{x}=2.33$ in the $2003 / 2004$ school year, $\bar{x}=2.28$ in $2016 / 2017$ ) (more in Szczurek-Boruta, 2019b, pp. 39-61). Due to biological unity of youth, developmental tasks are shared by all adolescents. In their development, the young go through a similar training and are subjected to similar influences. The similarity of social expectations, which the young provide with individual contents, results from the impact of the common borderland culture and social pressure. The both examined generations, Y and Z, have a lot in common - they live in the world of media, they have gone through educational reforms, social expectations from them have not changed over the time, they have similar learning achievements and deficits in soft skills. As Havighurst noticed in his concept, the main forces which influence each other in developmental tasks are individual needs, the normal growth process and social pressures, cultural models.

Developmental tasks put the individual into particular developmental contexts. These contexts, though strongly individualized, are strictly related to social and cultural contexts. Personal tasks are associated with the social roles which an individual fulfils in compliance with the currently binding cultural models (Havighurst \& Taba, 1963, p. 89). The relations between biological, psychological and sociocultural factors might enhance the fulfilment of developmental tasks, but they can also trigger some situations of dramatic tensions, conflicts and crises.

An essential role in the acquisition of developmental tasks is played by the ability to generate positive solutions and acting, based on or under the pressure of challenges and

\footnotetext{
${ }^{8}$ Generation Y - people born in the mid-1990s, examined in the school year 2003/2004; generation Z - people born at the end of the 20th century, examined in the school year 2016/2017 (WJSchroer, 2020).
} 
changes. The significance of creative resilience in human activities seems to be confirmed by Fredrickson's (2001) research results.

Some explanations in regard to this are also provided by Fuentes (2017), an anthropologist, who notices that creativity is the main reason of people's unique adaptive ability. Creativity and collaboration have led humanity to its development.

The relationships between resilience and creativity are also indicated by Metzl and Morrell (2008). They present both a model which takes into account the role of personal creativity in the processes of resilience and the suggestions for practical application in therapeutic work and future research.

The similarity of research results obtained in both cohorts surely results from the similarity in the repeatability of the developmental model. It should be noticed that childhood of the studied groups falls in the times of the information society, network society, media society, access age (Beniger, 1986; Castells, 2010; Melucci, 2001). A similar quality of educational offers and the ways of using them in the examined cohorts can be noticed as well. Schools led youth with different individual and social resources and living in different sociocultural times to a similar size of identity capital (a similar level of identity forming), they made the young from both cohorts similar (Szczurek-Boruta, 2019b, pp. 61-67). Educational institutions have been focusing on the reproduction of social order and on maintaining and educating young people on an average level.

The conducted statistical analyses point to the stability and similarity of social conditions of education (the average value $\bar{x}=2.045$ in the 2003/2004; $\bar{x}=2.159$ in 2016/2017, the $5.6 \%$ increase allows one to think optimistically about slow changes in this field) and their interrelation with the fulfilment of developmental tasks $(r=0.682 ; \mathrm{p}<0.001$ in the 2003/2004; $r=0.73757$ chi-squared $(1482)=2091.0 ; p=0.000$ in 2016/2017) (Szczurek-Boruta, 2019b, pp. 104-105). The sociocultural environment of the borderland, residence place (town/country), family, school, peer group are the resources that contribute to the reproduction of cultural capital, and in turn - of social structure. An empirical image of social conditions of education shows that youth receives a similar systematic support from parents, teachers and the local community in their struggle with consecutive tasks in life.

The conducted factor analysis enabled the distinguishing of five main factors/dimensions of education: individual/inner factors (identity, learning); social/outer ones (family environment, school, culture-related local community); practice (training in resistance, overcoming difficulties and crises); educational measures, and presenting a model of education from the thermodynamic perspective (cf. Szczurek-Boruta, 2019b, pp. 146-160).

The research the outcomes of which are provided above has contributed to the identification of the conditions of adaptation taking place in the borderland, risk factors and outer protective factors (feeling of stability and safety, school education, peer relationships) as well as inner ones (values, competences), which all determine positive adaptation.

The research results and their analyses, presented here with certain abridgement and simplification, do not cover the whole large problem field of positive adaptation and its determinants. However, they constitute a general foundation for further discussion. 


\section{Discussion}

The results of the studies conducted among generations of youth indicate their positive adaptation in the social and individual dimension. What can be its measure is the possessing of psychosocial adaptive competences. The results indirectly point to the relatively good mental health of the respondents and good quality of their life.

An interactive nature of resilience necessitates taking into account in the analyses, apart from competence, also the exposure of a young person to threat-related factors and to the resources which the young use to maintain their relatively good mental health.

My studies indicated the effect of accumulation of many risk and protective factors (the interactions of protective and risk factors are focused on by the already mentioned Luthar \& Bidwell Zelazo, 2003; Werner, 2000, as well as Fergus \& Zimmerman, 2005; Borucka, 2011).

They can be treated in several basic dimensions that are the source of influence on an individual's development (individual profile, peer influences, family relations, characteristics of the residence place) and can be referred to the dimensions of borderlands: the personal (the borderland affects the personality of its inhabitants), the sociocultural (a typical feature of borderlands is the distinction into the own and the alien), and the territorial dimension (spatial closeness enhances the intended and unintended contacts among nationally, ethnically, culturally and religiously differentiated population) (Sadowski, 1992).

Young people functioning in the borderland have cognitive competences which enable them to notice and describe themselves in the categories of their own person and other people, groups or institutions. They consciously take part in the social life of the region. This results in the developing of various types of their identity: a social, cultural, regional, national, European, global one. A young person is able to achieve the integrity of their identity. The researchers into the Polish-Czech borderland ${ }^{9}$ share Nikitorowicz (1995) views on the shaping of the multi-dimensional identity. They conclude that the shaping of the borderland man's identity requires - on the one hand - cultural rooting, internalization of values, beliefs and the related behaviour patterns that determine the competences to participate in the community, and - on the other - educational activities and the support of the educational policy, aiming at future, progress and development. In the borderland environment, there are rich resources for positive development and the enhancing of healthy behaviour - protective resources and support. What is of substantial significance is the creative interaction of humanity and culture (Lewowicki et al., 2013). The role of culture in the mental development and forming of human behaviour patterns is widely understood and appreciated (Przetacznik-Gierowska \& Tyszkowa, 2021). The young's experience is acquired by them and then considered in the sociocultural context of their life (Brzezińska, 2020). This context is an important source of experience and information about people, values and cultural models. Youth can see these resources and make use of them. What can exemplify protective factors are contacts with adults.

\footnotetext{
9 The results referred to here come from the team studies, in which I took part, conducted in 1990-2011 in the Polish-Czech borderland under the scientific supervision of Lewowicki. They have been published in over 80 collective and individual works in the series Intercultural Education (in Polish: Edukacja Międzykulturowa).
} 
Youth search for a place in the social structure - an identification. A guarantor of youth's physical, mental and emotional safety, as well as of their financial stability and support is family. The results of many studies carried out in the Polish-Czech borderland indicate that the family provides support and anchoring in values (Świątkiewicz, 2007; Janeczek \& Szczepański, 2006). It is a source of traditions and an environment in which the transmission of values takes place. Family is a determinant of shaping the cultural foundations of national awareness (Bukowska-Floreńska, 1997), as well as of identity shaping in childhood and youth (Szczurek-Boruta, 2017). In many cases, it is a place where positive intergenerational relations are shaped. Strong bonds of a child with parents or the presence of other people constitute support for an individual. Parents engage in the child's learning and other matters. They perceive education as a chance for their children's better life. Unchangeably, education and learning are important values for the inhabitants of the Polish-Czech borderland (Szczurek-Boruta, 2000).

The Polish-Czech borderland is a good residence environment with great natural and cultural assets (values, traditions) and a high quality of school education (efficient work of schools). The results of my own studies indicate the educational value of the cultural borderland (Szczurek-Boruta, 2004, 2011, 2014). Secondary schools effectively prepare the young for school leaving exams and the undertaking of university education, they ensure school success. In the examined borderland, the pass rate of learners taking final school exams is higher in comparison to the exam results in other counties and communes of the SV (82.94 points whereas the average level is 77.17 points) (Okręgowa Komisja Egzaminacyjna w Jaworznie, 2017).

The discussed borderland has a large sociocultural and personal capital. The issue of the sociocultural and human capital has been discussed in my other study (see Szczurek-Boruta, 2008). The description of this capital consists mostly of the resources of (spiritual and material) culture, history and traditions of the region, specificity of culture, institutions which deal with these resources, including school education and human resources. These are not all the constituents of the capital, as the full description is practically not feasible, but only the major ones that are recognized in typical characterizations of the social, cultural or human capital (Jasiński et al., 1998). The description can be supplemented and broadened with the basic information about the economic potentialities and collaboration in various fields of life in the borderland region. The examined youth's situation on the labour market is good (in comparison to other voivodeships, one of the lowest unemployment rates, the highest number of job offers, the lowest number of the registered unemployed per one work offer) (Urząd Statystyczny w Katowicach, 2020). This is noticed by young people who positively assess the possibilities of finding a job in the region and often postpone the decision about undertaking professional work.

What deserves due attention while presenting a profile of the Polish-Czech borderland as an environment and place of life for young people are the political interrelations between Poland and the Czech Republic, which are deeply rooted in the foundations of Polish-Czech relationships (Chlebowczyk, 1975; Bazielich, 1995). The frequent changes in this region's state belonging, the long and difficult history of the Polish-Czech neighbourhood, the manifestations of tolerance/intolerance, both mutual acceptance or even liking and unwillingness, the 
change from a neutral (to nationality issues) region into a region of animosity between Poles and Czechs have all left their marks on the mentality of the residents. The Polish-Czech borderland is a territory of two states, in which there is a distinct awareness of social distinctness. This is confirmed by the studies and analyses conducted by various authors (Chlebowczyk, 1975, 1983; Lewowicki, 1994; Szczurek-Boruta, 2017).

An important role in the process of positive adaptation in the discussed borderland can be attributed to the specificity of its culture (Lipok-Bierwiaczonek, 1994). The region has been shaped under the influence of the Polish, Czech (Moravian) and also German culture. The impact of the Jewish and Roma culture has also been observed (Gawrecká \& Gwarecki, 2007). Spatial closeness, natural contacts and permeating of cultures have enhanced openness and the shaping of the complex, multidimensional identity. This is proved by the evidence provided by the results of many studies conducted in the Polish-Czech borderland (by the team supervised by Lewowicki) ${ }^{10}$, as well as in other borderlands of Poland (e.g. the research into the Polish-Belarussian borderland carried out by Nikitorowicz) ${ }^{11}$. In regard to the cultural specificity of the region (the Polish-Czech borderland), its multiculturalism (Zieliński, 1997, p. 55-67) and multireligiousness (two denominations prevail: the Roman Catholic Church and the Evangelical Church of the Augsburg Confession in Poland) can be mentioned. This multireligiousness has created favourable conditions both for a specific, enriching competition in cultural, educational or literary activity and for developing integration tendencies as well as undertaking ecumenical activities (Lewowicki et al., 2016). The regional system of culture stems from many years of the permeating of diverse cultures and traditions. The elements of both Polish and Czech traditions are present in lay and sacral architecture (Szczepański, 1999).

The disappearance of inner borders of the EU created new conditions for changes in the economic, political and mostly sociocultural space of the Polish-Czech borderland. Transborder cooperation is developing successfully: in economy - collaboration of entrepreneurs; in transport - development of infrastructural networks; in culture, sport and tourism; in education and science (scientific research, cooperation and co-implementation of EU projects); in combating crime; in warning of and supporting in catastrophes (e.g. flood risk) (Wróblewski, 2020). A visible manifestation of the activity of the Polish-Czech Euroregions is a variety of forms of transfrontier and territorial cooperation and the effects of micro-projects implemented by these Euroregions (Kasperek, 2014). The diffusion process of various systems of material and symbolic culture is progressing, the residents use their native but also their neighbours' language (the latter is often present in the educational system), the official state ceremonies are recognized and celebrated by the neighbours.

\footnotetext{
${ }^{10} \mathrm{Cf}$. the results of the team studies conducted since the early 1990s, in which the author of this article has taken part, presented in the works edited by Lewowicki, e.g. The Sense of Identity and Young People's Attitude to Selected Social Issues: A Study from the Polish-Czech Border (in Polish: Poczucie tożsamości i stosunek młodzieży do wybranych kwestii społecznych - studium z pogranicza polsko-czeskiego) (Lewowicki et al., 1994); Youth Communities in the Borderland (in Polish: Społeczności młodzieżowe na Pograniczu) (1995b); in total, over 80 volumes published in the series Intercultural Education.

${ }^{11} \mathrm{Cf}$. the research results presented in the studies edited by Nikitorowicz, e.g. Youth from the Cultural Borderland of Belarus, Poland and Ukraine in the Face of European Integration: Identity, Life Plans, Values (in Polish: Młodziez pogranicza kulturowego Białorusi, Polski, Ukrainy wobec integracji europejskiej. Tożsamość, plany życiowe, wartości (2000) and other works published in Białystok, Poland by Trans Humana Publishing House.
} 
Previously, the residence place did not determine the place of work (workers walked from Poland to work in Czech steelworks) and today it does not do this as well (since joining the Schengen Area, the phenomenon has been getting more popular and intensive, Polish miners work in Czech coal mines). The same concerns shopping and making use of tourist offers. The daily movement of labour force in the borderland is a normal phenomenon. What comes into being here is a new quality of life - without territorial borderlines experienced by borderland residents but still with mental borders. This enables the manifestation of cultural and social distinctness with the simultaneous acceptance of the borderland community:

\begin{abstract}
"There are permanent elements in the image of the borderland man's identity. These are people, the place (space), symbols and values. The nearest (parents, siblings, relatives) get rooted in the cultural space. Other people (guardians, teachers, tutors, important people) function as role models and are both the background and the mirror for the identity that is being formed. An identity is specified in human contacts and constructed by giving meanings to different symbols - they remain the same but the form and the way of passing them down (e.g. new communication technologies) changes" (Szczurek-Boruta, 2019a, p. 428).
\end{abstract}

The relations in the territory of the Polish-Czech borderland gained a new dimension after 2004, when both countries joined the EU. The fields of cultural co-existence are clearly indicated: language, tradition, religion, architecture, science, education and tourism (Pindór, 2015).

The indicators associated with a good quality of education are shown in the analyses of the residents' level of education. In comparison to the national average, the inhabitants of the investigated borderland have an analogous level of education (the Statistics Poland (SP) data) (Główny Urząd Statystyczny, 2020; Polska w liczbach, 2020). The institution which fulfils important culture-creating and scientific functions in the region is the Faculty of Arts and Educational Science (former Faculty of Ethnology and Educational Science) at the University of Silesia in Katowice (USK), Poland - a scientific centre which undertakes research into e.g. social, cultural and educational determinants shaping the identity of children and youth. This is an important centre educating both teachers and cultural animators. The traditions of education for teachers here reach as far as 110 years ago (Mrózek \& Szuścik, 2013). In 2021, the Cieszyn Campus of the USK celebrates its 50th anniversary (see Uniwersytet Śląski w Katowicach, 2021).

A factor that determines the development, the feeling of the residents' quality of life is the economic potential. Unceasingly for many years, the good local labour market (low unemployment), a high (in the scale of Poland) gross domestic product per capita, a stable birth rate, a negative balance of migration, a dense and diversified school network, and a big number of sociocultural institutions and organizations have created good conditions for education and life for the inhabitants of the Polish-Czech borderland (the SP data for the SV) (Główny Urząd Statystyczny, 2020; Polska w liczbach, 2020).

The mechanism of positive adaptation in the borderland is a certain rather specific strategy. What can be indicated here is exerting social influence on the individual through creating particular temporal-spatial-technical conditions, in which the individual will notice a change and will react to it, and exerting social impact through specific influence of members of important (for the individual) social groups, e.g. parents, peers, teachers, other significant 
people in the environment. This influence takes place in the process of socialization and education through imposing upon the individual some particular behaviour patterns implemented in the process of adaptation. To be more precise, this pertains to an intervention which causes that the individual chooses a specific pattern out of the repertoire of the available patterns in this situation (some examples of such activities, behaviours and strategies are presented in the publications in the publishing series Social Pedagogy (in Polish: Pedagogika Społeczna in 2014-2019, e.g. Szczurek-Boruta et al., 2014; Szczurek-Boruta \& ChojnackaSynaszko, 2015).

On the basis of the conducted studies and analyses, it can be stated that social resources personal relations and bonds (with family, friends, others) - and a feeling of belonging (to the place of life) are equally important for building resilience as the inner mental resources (creativity). Resilience can be cherished by daily activities. Personal creativity provides hope for a successful solution to inevitable challenges in life, education and work, which results in transformation.

Everything written here so far entitles me to a positive verification of the stated thesis. What has come into being, in the specific borderland conditions discussed above, is the inhabitants' flexibility, their creative effort that alleviates the tensions and contradictions between the constant inherited elements and the changeable ones, people's ability to handle everyday life situations - the inhabitants have resistance-based behaviour patterns. Due to its character, the borderland is a source of and a stimulant for acquiring the resilience disposition by its residents. The interactive nature of resilience is revealed in the borderland, which allows one for active participation and mutual influence.

\section{Conclusions}

The conducted studies as well as their results and analyses show the psychosocial and psychocultural effects of the borderland location on the development of youth.

In regard to the obtained research results, a positive, creative adaptation of youth to constantly changing requirements can be observed. An important role in this process should be attributed to the environmental resources, which interact with individual powers. Adaptation is enhanced by familiarization with the complex nature of borderlands - i.e. the experience of rooting in the tradition, the awareness of tensions typical of borderland dynamics, the attitude of a human open to cultural and religious diversity. Resilience results from the primary socialization, secondary socialization, the natural process of acquiring cultural competences, handling changes, and contradictions, balancing in situations of tension, which bring about the risk of self-destruction of the identity. The experiencing of risk and an individual's use of the resources of the borderland environment lead to the development and reflective distinctness of one's - as if germinating - resilience.

Resilience is dynamic and it is unceasingly developing and forming in any borderlands. Borderlands are not "anywhere far", they are not situated in any remote or even mythical frontiers - their more or less distinct presence, their specific qualities and their peculiar dynamic systems of values, comply with diverse areas of human existence, as a co-forming and identity-shaping factor. 
The active inclusion of creativity to the general model of resilience opens to educators a significant and promising current of research into educational interventions, which contributes to better familiarization with the determinants of positive adaptation of children and youth and, at the same time, provides scientific foundations for the development of programmes promoting mental health and prevention of mental and behavioural disorders. Applying the concept of resilience to indicate the mechanisms of positive adaptation of an individual ensures the effectiveness of educational influences. It is used to elaborate and implement programmes aimed at supporting positive development, i.e. programmes that are to facilitate youth's life skills and interpersonal relations with parents and other significant people (mentors), as well as positive qualities of the school environment and residence place.

The studies on positive (creative) adaptation in borderland conditions constitute a foundation for preparing programmes based on a better use of protective resources and factors which exist in the environment of life. This is confirmed by the presented analyses, which show certain tendencies and mechanisms that are universal for human behaviour and the community. Borderland is a laboratory which explains mechanisms of people's behaviour patterns - and not only of the people living in borderlands. The conducted analyses are useful for recognizing and constructing a new order in the societies that are being shaped. They indicate the need to undertake educational activities aimed at developing and shaping human resilience.

The phenomena discussed in this study, especially their interpretations, should be read out as preliminary and mostly hypothetical responses to the problem put forward in the title of this article.

\section{References}

Barron, F. (1969). Creative person and creative process. Holt, Rinehart and Winston, Inc.

Bazielich, B. (Red.). (1995). Śląsk - etniczno-kulturowa wspólnota i różnorodność. Sudety.

Beniger, J. R. (1986). The control revolution: Technological and economic origins of the information society. Harvard University Press.

Borucka, A. (2011). Koncepcja resilience. Podstawowe założenia i nurty badań. In W. Junik (Ed.), Teoria - Badania - Praktyka. Resilience (pp. 11-28). Wydawnictwo Edukacyjne PARPAMEDIA.

Brzezińska, A. (2020). Wykłady z Psychologii. T. 3. Społeczna psychologia rozwoju. WN Scholar.

Bukowska-Floreńska, I. (1997). Rodzina a kulturowe podstawy świadomości narodowej. In Z. Jasiński \& A. Kozłowska (Red.), Tożsamość narodowa młodzieży na pograniczach (pp. 57-62). Opolska Oficyna Wydawnicza.

Castells, M. (2010). The information age: Economy, society, and culture. Vol. 3: End of Millennium. John Wiley \& Sons, Ltd.

Chlebowczyk, J. (1983). O prawie do bytu małych i młodych narodów. Kwestia narodowa i procesy narodotwórcze we wschodniej Europie środkowej w dobie kapitalizmu (od schyłku XVIII do początków $X X$ w.). ŚIN/PWN.

Chlebowczyk, J. (1975). Procesy narodotwórcze we wschodniej Europie środkowej w dobie kapitalizmu (od schylku XVIII do poczatków XX w.). Państwowe Wydawnictwo Naukowe/Ślaski Instytut Naukowy.

Csikszentmihalyi, M. (1996). Creativity: The psychology of discovery and invention. HarperPerennial/ ModernClassics. 
Erikson, E. H. (1994). Identity and the life cycle. W. W. Norton \& Company.

Fergus, S., \& Zimmerman, M. A. (2005). Adolescent resilience: A framework for understanding healthy development in the face of risk. Annual Review of Public Health, 26, 399-419. https://doi.org/10.1146/annurev.publhealth.26.021304.144357

Ferguson, G. A. (1989). Statistical analysis in psychology and education. McGraw-Hill, Inc.

Frankfort-Nachmias, Ch., \& Nachmias, D. (1996). Research methods in the social sciences. Worth Publishers.

Fredrickson, B. L. (2001). The role of positive emotions in positive psychology: The Broaden-and-Build theory of positive emotions. American Psychologist, 56(3), 218-226. https://doi.org/10.1037/0003-066X.56.3.218

Fuentes, A. (2017). The creative spark: How imagination made humans exceptional. Penguin Random House LLC.

Gawrecká, M., \& Gwarecki, D. (2007). Česko-polské vztahy ve Slezsku z historické perspektivy. In D. Berlińska \& M. Korzeniowski (Red.), Tożsamość lokalna, regionalna, transgraniczna na pograniczu polsko-czeskim. Lokální, regionalní atranshranični identita v polsko-českèm pohraničí (pp. 28-37). Wydawnictwo Instytut Śląski.

Główny Urząd Statystyczny. (2020). Rocznik Statystyczny Województw 2018. https://stat.gov.pl/obszary-tematyczne/roczniki-statystyczne/roczniki-statystyczne/rocznik-statystyczny-wojewodztw-2018,4,13.html

Gołdyka, L. (2016). Uwagi o efekcie pogranicza. In J. Miluska (Red.), Psychologia społeczno-kulturowego pogranicza. Wstęp do koncepcji i badan (pp. 15-30). Wydawnictwo Naukowe Wydziału Humanistycznego Uniwersytetu Szczecińskiego Minerwa.

Havighurst, R. J. (1981). Developmental tasks and education. Longman.

Havighurst, R. J., \& Taba, H. (1963). Adolescent character and personality. John Wiley and Sons.

Janeczek, J., \& Szczepański, M. S. (Eds.). (2006). Dynamika śląskiej tożsamości. Wydawnictwo Uniwersytetu Śląskiego.

Jasiński, Z., Lewowicki, T., \& Nikitorowicz, J. (Red.). (1998). Potencjał społeczno-kulturowy polskich pograniczy. Opolska Oficyna Wydawnicza.

Kasperek, B. (Red.). (2014). Euroregiony pogranicza polsko-czeskiego. Stowarzyszenie Rozwoju i Współpracy Regionalnej Olza.

Lewowicki, T. (1995a). O badaniach społeczności pogranicza - od parcjalnych opisów ku elementom teorii zachowań tożsamościowych. In J. Nikitorowicz (Red.), Edukacja międzykulturowa. W kręgu potrzeb, oczekiwań i stereotypów (pp. 13-27). Wydawnictwo Uniwersyteckie Trans Humana.

Lewowicki, T. (Red.) (1995b). Społeczności młodzieżowe na pograniczu: praca zbiorowa. Uniwersytet Śląski. Filia.

Lewowicki, T. (1994). Poczucie tożsamości narodowej młodzieży - stałość - zmienność. In T. Lewowicki, E. Ogrodzka-Mazur, \& A. Szczurek-Boruta (Red.), Poczucie tożsamości i stosunek młodzieży do wybranych kwestii społecznych - studium z pogranicza polsko-czeskiego (pp. 127-135). Wydawnictwo Adam Marszałek.

Lewowicki, T., Grabowska, B., Klajmon-Lech, U., \& Różańska, A. (2016). Sfery życia duchowego dzieci i młodzieży. Studium z pogranicza polsko-czeskiego. T. 2: Religia i tolerancja religijna. Wydawnictwo Adam Marszałek.

Lewowicki, T., Szczurek-Boruta, A., \& Grabowska, B. (Eds.). (2013). Kultura w edukacji międzykulturowej - konteksty teoretyczne i społeczno-polityczne. Wydawnictwo Adam Marszałek.

Lipok-Bierwiaczonek, M. (1994). Więzi kulturowe pogranicza polsko-czeskiego (Ślask Cieszyński, Ślask Opawski, Raciborskie). Fundacja Przestrzeni Górnego Śląska. 
Łobocki, M. (1999). Wprowadzenie do metodologii badań pedagogicznych. Oficyna Wydawnicza Impuls.

Luthar, S. S. (Ed.). (2003). Resilience and vulnerability: Adaptation in the context of childhood adversities. Cambridge University Press. https://doi.org/10.1017/CBO9780511615788

Luthar, S. S. (2006). Resilience in development: A synthesis of research across five decades. In D. Cicchetti \& D. J. Cohen (Eds.), Developmenthal psychopatology. Vol. 3: Risk, disorder, and adaptation (pp. 739-795). John Wiley \& Sons, Inc. https://doi.org/10.1002/9780470939406.ch20

Luthar, S. S., \& Bidwell Zelazo, L. (2003). Research on resilience: An integrative review. In S. S. Luthar (Ed.), Resilience and vulnerability: adaptation in the context of childhood adversities (pp. 510-550). Cambridge University Press. https://doi.org/10.1017/CBO9780511615788.023

Luthar, S. S., Cicchetti, D., \& Becker, B. (2000). The construct of resilience: A critical evaluation and guidelines for future work. Child Development, 71(3), 543-562. https://doi.org/10.1111/1467-8624.00164

Luthar, S. S., Sawyer, J. A., \& Brown, P. J. (2006). Conceptual issues in studies of resilience: Past, present, and future research. Annals of the New York Academy of Sciences, 1094(1), 105-115. https://doi.org/10.1196/annals.1376.009

Masten, A. S., \& Obradović, J. (2006). Competence and resilience in development. Annals of the New York Academy of Sciences, 1094(1), 13-27. https://doi.org/10.1196/annals.1376.003

Masten, A. S., \& Powell, J. L. (2003). A resilience framework for research, policy and practice. In S. S. Luthar (Ed.), Resilience and vulnerability: Adaptation in the context of childhood adversities (pp. 1-26). Cambridge University Press. https://doi.org/10.1017/CBO9780511615788.003

Melucci, A. (2001). Challenging codes: Collective action in the information age. Cambridge University Press.

Meneely, J., \& Portillo, M. (2005). The adaptable mind in design: Relating personality, cognitive style, and creative performance. Creativity Research Journal, 17(2-3), 155-166. https://doi.org/10.1207/s15326934crj1702\&3_3

Metzl, E. S., \& Morrell, M. A. (2008). The role of creativity in models of resilience: Theoretical exploration and practical applications. Journal of Creativity in Mental Health, 3(3), 303-318. https://doi.org/10.1080/15401380802385228

Miluska, J. (Ed.) (2016). Psychologia społeczno-kulturowego pogranicza. Wstęp do koncepcji i badań. Wydawnictwo Naukowe Wydziału Humanistycznego Uniwersytetu Szczecińskiego Minerwa.

Mrózek, R., \& Szuścik, U. (Red.). (2013). Z przeszłości i współczesności kształcenia pedagogicznego w Cieszynie. Wydawnictwo Uniwersytetu Śląskiego.

Nęcka, E. (2001). Psychologia twórczości. Gdańskie Wydawnictwo Psychologiczne.

Nikitorowicz, J. (2000). Młodzież pogranicza kulturowego Białorusi, Polski i Ukrainy wobec integracji europejskiej. Tożsamość, plany życiowe, wartości. Trans Humana Wydawnictwo Uniwersyteckie.

Nikitorowicz, J. (1995). Pogranicze, tożsamość, edukacja międzykulturowa. Wydawnictwo Uniwersyteckie Trans Humana.

Okręgowa Komisja Egzaminacyjna w Jaworznie. (2017). Egzamin maturalny 2017 w województwie śląskim. Wyniki egzaminu w powiatach i gminach. http://oke.jaworzno.pl/wyniki/matura/2017_matura_powiaty_gminy.pdf

Olsson, C. A., Bond, L., Burns, J. M., A Vella-Brodrick, D., \& Sawyer, S. M. (2003). Adolescent resilience: A concept analysis, Journal of Adolescence, 26(1), 1-11. https://doi.org/10.1016/S0140-1971(02)00118-5

Pindór, M. (2015). Przestrzeń współbycia. “Těšínské niebo Cieszyńskie nebe” Těšínského divadla w Českém Těšíně jako międzykulturowa narracja o wielokulturowości miasta/miast. Edukacja Międzykulturowa, 4, 285-302. https://doi.org/10.15804/em.2015.17

Polska w liczbach. (2020). Polska - podstawowe informacje. https://www.polskawliczbach.pl/ 
Przetacznik-Gierowska, M., \& Tyszkowa, M. (2021). Psychologia - klasyczne podręcznik. Psychologia rozwoju człowieka. T. 1: Zagadnienia ogólne. Wydawnictwo Naukowe PWN.

Rubacha, K. (2008). Pedagogika Wobec Wspótczesności. Metodologia badań nad edukacją. Wydawnictwa Akademickie i Profesjonalne.

Rutter, M. (2006). Implications of resilience concepts for scientific understanding. Annals of the New York Academy of Sciences, 1094(1), 1-12. https://doi.org/10.1196/annals.1376.002

Sadowski, A. (2008). Pogranicze - pograniczność - tożsamość pograniczna. In H. Bojar, D. Wojakowski, \& Sadowski, A. (Red.), Pogranicze. Studia Społeczne (pp. 17-30). T. 14: Polskie granice i pogranicza: nowe problemy i interpretacje. Wydawnictwo Uniwersytetu w Białymstoku.

Sadowski, A. (1992). Pogranicze. Zarys problematyki. In A. Sadowski (Red.), Pogranicze. Studia Społeczne (pp. 5-8). T. 1. Dział Wydawnictw Filii Uniwersytetu Warszawskiego w Białystoku.

Schaie, K. W., \& Strother, Ch. R. (1968). A cross-sequential study of age changes in cognitive behavior. Psychological Bulletin, 70(6.1), 671-680. https://doi.org/10.1037/h0026811

Simonet, G., \& Duchemin, E. (2010.) The concept of adaptation: Interdisciplinary scope and involvement in climate change. Sapiens, 3(1). https://journals.openedition.org/sapiens/997

Szczepański, M. S. (1999). Region pogranicza kulturowego w perspektywie socjologicznej: przypadek Górnego Śląska. Studia etnologiczne i antropologiczne, 2, 161-180.

Szczurek-Boruta, A. (2019a). Człowiek pogranicza i jego poczucie tożsamości - na przykładzie wybranych badań społeczności regionu pogranicznego. In M. Sobecki, D. Misiejuk, J. Muszyńska, \& T. Bajkowski (Red.), Człowiek pogranicza. Wyzwania humanistycznej edukacji (pp. 420-429). Wydawnictwo Uniwersytetu w Białystoku.

Szczurek-Boruta, A. (2019b). Zadania rozwojowe i edukacja szkolna młodzieży. Stałość i zmienność. Wydawnictwo Adam Marszałek.

Szczurek-Boruta, A. (2011). Edukacyjne konteksty kształtowania poczucia tożsamości kulturowej młodzieży - studia i doświadczenia z pogranicza polsko-czeskiego. In J. Nikitorowicz, M. Sobecki, \& J. Muszyńska (Red.), Pogranicze. Studia Społeczne (pp. 141-165). T. 17.2: Edukacja międzykulturowa. Dział Wydawnictw Filii Uniwersytetu Warszawskiego w Białystoku. https://doi.org/10.15290/pss.2011.17.02.10

Szczurek-Boruta, A. (2004). Edukacyjna wartość kulturowego pogranicza - powinności edukacyjne wybrane przykłady realizacji edukacji międzykulturowej i Europejskiej (studium z pogranicza polsko-czeskiego). in A. Paszko (Red.), Edukacja międzykulturowa w Polsce na przełomie XX i XXI wieku: praca zbiorowa (pp. 49-60). Wojewódzka Biblioteka Publiczna.

Szczurek-Boruta, A. (2014). Intercultural education in Cieszyn Silesia. American Journal of Educational Research, 2(3), 154-158. https://doi.org/10.12691/education-2-3-8

Szczurek-Boruta, A. (2008). Kapitał społeczno-kulturowy i poczucie tożsamości wielowymiarowej na Śląsku Cieszyńskim. Studia Edukacyjne, 8, 87-104.

Szczurek-Boruta, A. (2000). Oddziaływania socjalizacyjno-wychowawcze w rodzinie w zróżnicowanym środowisku Pogranicza. In T. Lewowicki \& J. Suchodolska (Red.), Rodzina wychowanie wielokulturowość (pp. 117-140). Uniwersytet Śląski - Filia w Cieszynie, Wyższa Szkoła Pedagogiczna ZNP w Warszawie.

Szczurek-Boruta, A. (2017). Tożsamość młodych Polaków mieszkających na pograniczu polsko-czeskim. In J. Nikitorowicz, J. Muszyńska, \& A. Sadowski (Red.), Pogranicze. Studia Społeczne (pp. 195209). T. 30: Polityka edukacyjna - tożsamość - edukacja międzykulturowa. Wydawnictwo Uniwersytetu w Białymstoku. https://doi.org/10.15290/pss.2017.30.14

Szczurek-Boruta, A. (2007). Zadania rozwojowe młodzieży i edukacyjne warunki ich wypetniania w środowiskach zróżnicowanych kulturowo i gospodarczo. Studium pedagogiczne. Wydawnictwo Uniwersytetu Śląskiego. 
Szczurek-Boruta, A., \& Chojnacka-Synaszko, B. (Red.). (2015). Szkoła - kultura - środowisko lokalne. Wydawnictwo Adam Marszałek.

Szczurek-Boruta, A., Chojnacka-Synaszko, B., \& Suchodolska, J. (Red.). (2014). Człowiek w przestrzeni lokalnej - dobre praktyki wspierania rozwoju, aktywizacji i integracji społeczne. Konteksty teoretyczne i społeczno-polityczne. Wydawnictwo Adam Marszałek.

Śliż, A., \& Szczepański, M. S. (2016). Pogranicze polsko-czeskie w perspektywie socjologicznej. Kontekst kulturowy. In A. Sadowski \& K. Sztop-Rutkowska (Red.), Pogranicze. Studia Społeczne (pp. 4759). T. 27.1: Procesy transkulturowe na pograniczach. Wydawnictwo Uniwersytetu w Białymstoku. https://doi.org/10.15290/pss.2016.27.01.03

Świątkiewicz, W. (2007). Rodzina jako wartość społeczna. In W. Świątkiewicz (Red.), W trosce o rodzinę: Ksiega pamiątkowa ku czci Profesor Wandy Stojanowskiej (pp. 8-31). C. H. Beck.

Thomas, R. M. (Ed.). (1990). The encyclopedia of human development and education: Theory, research, and studies. University of California.

Trudel, M., Chaussegros de Léry, É., \& Puentes-Neuman, G. (2001). Régulation biocomportementale des réponses d’adaptation au stress chez les jeunes enfants. In M. Dumont \& B. Plancherel (Eds.), Collection D'Enfance. Vol. 8. Stress et adaptation chez l'enfant (pp. 29-52). Presses de l'Université du Québec.

Uniwersytet Śląski w Katowicach. (2021). 50 lat Uniwersytetu Śląskiego w Cieszynie. https://us.edu.pl/ wydzial/wsne/50-lat-us-w-cieszynie/?doing_wp_cron=1625237160.4364531040191650390625

Urząd Statystyczny w Katowicach. (2021). Bezrobocie w województwie śląskim w 2016 r. https://katowice.stat.gov.pl/opracowania-biezace/opracowania-sygnalne/praca-wynagrodzenie/bezrobocie-w-wojewodztwie-slaskim-w-2016-r-,3,6.html

Werner, E. E. (1994). Overcoming the odds. Journal of Developmental and Behavioral Pediatrics, 15(2), 131-136. https://doi.org/10.1097/00004703-199404000-00012

Werner, E. E. (2000). Protective factors and individual resilience. In J. P. Shonkoff \& S. J. Meisels (Eds.), Handbook of early childhood intervention (pp. 115-132). Cambridge University Press. https://doi.org/10.1017/CBO9780511529320.008

WJSchroer. (2020). Generations X, Y, Z and the others. http://socialmarketing.org/archives/generationsxy-z-and-the-others/

Wróblewski, Ł. (Red.). (2020). Śląsk Cieszyński w świetle wyzwań i zagrożeń XXI wieku. Polska Akademia Nauk Oddział w Katowicach/Stowarzyszenie Rozwoju i Współpracy Regionalnej Olza.

Yates, T. M., Egeland, B., \& Sroufe, L. A. (2003). Rethinking resilience: A developmental process perspective. In S. S. Luthar (Ed.), Resilience and vulnerability: Adaptation in the context of childhood adversities (pp. 243-266). Cambridge University Press. https://doi.org/10.1017/CBO9780511615788.012

Zieliński, F. (1997). Wielokulturowość - typy i dramaty. In R. Cichocki (Ed.), Teorie społeczne a możliwości praktyczne. Materialy z konferencji naukowej Instytutu Socjologii UAM. Czerniejewo 11-12 kwietnia 1996 roku (pp. 55-67). Media-G.T. 